\section{(2) \\ BRAZIULIAN JOURNAL \\ OF MEDICAL AND BIOLOGICAL RESEARCH}

www.bjournal.com.br
ISSN 0100-879X

Volume 45 (6) 473-564 June 2012

BIOMEDICAL SCIENCES

AND

CLINICAL INVESTIGATION

Braz J Med Biol Res, May 2012, Volume 45(6) 497-501

doi: $10.1590 / \mathrm{S} 0100-879 X 2012007500049$

Experimental model of heterotopic ossification in Wistar rats

T.G.G. Zotz, J.B. de Paula and A.D.L. Moser

The Brazilian Journal of Medical and Biological Research is partially financed by

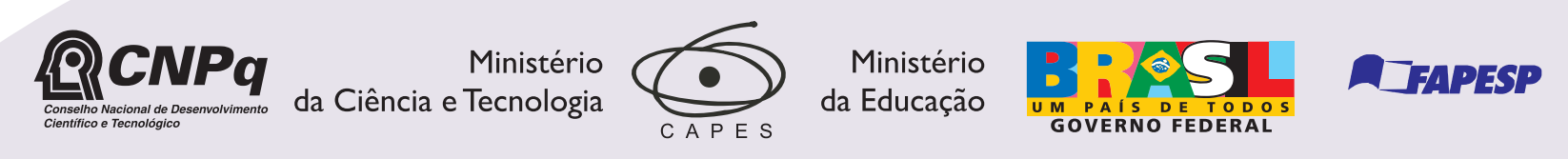

Institutional Sponsors

Scie/
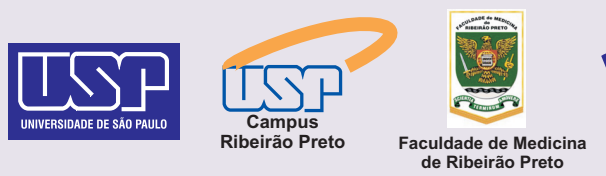

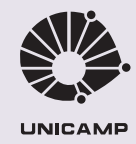

UNICAMP
Ф SHIMADZu

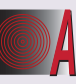

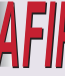

Associaçäo
Fundo
de Incentivo de lincentivo
aे Pesquisa

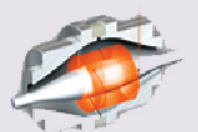

Explore High - Performance MS Orbitrap Technology andilice Thermo 


\title{
Experimental model of heterotopic ossification in Wistar rats
}

\author{
T.G.G. Zotz ${ }^{1}$, J.B. de Paula² and A.D.L. Moser ${ }^{1}$ \\ 1Escola Politécnica, Programa de Pós-Graduação em Tecnologia em Saúde, \\ Pontifícia Universidade Católica do Paraná, Curitiba, PR, Brasil \\ ${ }^{2}$ Médico, Doutor em Engenharia Biomédica, Curitiba, PR, Brasil
}

\begin{abstract}
Heterotopic ossification ( $\mathrm{HO}$ ) is a metaplastic biological process in which there is newly formed bone in soft tissues adjacent to large joints, resulting in joint mobility deficit. In order to determine which treatment techniques are more appropriate for such condition, experimental models of induced heterotopic bone formation have been proposed using heterologous demineralized bone matrix implants and bone morphogenetic protein and other tissues. The objective of the present experimental study was to identify a reliable protocol to induce $\mathrm{HO}$ in Wistar rats, based on autologous bone marrow (BM) implantation, comparing 3 different BM volumes and based on literature evidence of this $\mathrm{HO}$ induction model in larger laboratory animals. Twelve male Wistar albino rats weighing 350/390 g were used. The animals were anesthetized for blood sampling before HO induction in order to quantify serum alkaline phosphatase (ALP). HO was induced by BM implantation in both quadriceps muscles of these animals, experimental group (EG). Thirty-five days after the induction, another blood sample was collected for ALP determination. The results showed a weight gain in the EG and no significant difference in ALP levels when comparing the periods before and after induction. Qualitative histological analysis confirmed the occurrence of heterotopic ossification in all 12 EG rats. In conclusion, the $\mathrm{HO}$ induction model was effective when $0.35 \mathrm{~mL}$ autologous BM was applied to the quadriceps of Wistar rats.
\end{abstract}

Key words: Heterotopic ossification; Autologous bone marrow; Serum alkaline phosphatase

\section{Introduction}

Heterotopic ossification $(\mathrm{HO})$ is a metaplastic biological process in which newly formed bone is found in soft tissues adjacent to large joints (1-3), possibly leading to substantial disability (4).

The pathophysiology of $\mathrm{HO}$ is not completely understood, but osteoid formation commonly follows an inflammatory phase characterized by local swelling, pain, erythema, and sometimes fever and joint restriction $(1,2,4)$. It is associated with spinal cord and brain injuries, burns, fractures, muscle contusion, joint arthroplasty, lower motor neuron disorders, and hereditary disorders (1,5-7). HO induction was first reported in the 1930s $(8,9)$, and since then animal models have been used in different forms of $\mathrm{HO}$ induction in order to define techniques that may aid in the prevention and treatment of the condition.

The implantation of demineralized bone matrix is often used to induce ectopic bone formation (10-13), but this procedure is time-consuming and expensive and is not free of rejection risks. Another option is to induce $\mathrm{HO}$ by bone morphogenetic protein implantation; however, although this is an effective technique for bone tissue formation, not all laboratories have sufficient resources and technology for material extraction.

Thus, the purpose of the present study was to identify a reliable protocol for the induction of $\mathrm{HO}$ in Wistar rats by autologous bone marrow (BM) implantation based on the literature for larger laboratory animals.

\section{Material and Methods}

This study was approved by the University Ethics Committee in Animal Experiments, Pontifícia Universidade Católica do Paraná, No. 499/09. The experiment was divided into two phases. The first was a pilot study carried out to determine an effective induction protocol, and the second was the experiment itself.

The animals were kept in standard plastic cages under controlled environmental conditions (12/12-h light-dark cycle) with food and water ad libitum in the Pontifícia Universidade Católica do Paraná vivarium. The study was

Correspondence: T.G.G. Zotz, Rua Odete Laura Foggiato, 733B, 82630-040 Curitiba, PR, Brasil. E-mail: talita.gnoato@gmail.com

Received November 11, 2011. Accepted March 23, 2012. Available online April 5, 2012. Published June 4, 2012. 
conducted in accordance with international ethics standards for animal experimentation.

A total of 28 Wistar albino rats were used. The pilot study (first phase) used 16 adult male Wistar albino rats (Rattus norvegicus) weighing 300-350 g, approximately 3 months of age, divided into four groups of 4 rats each. Three groups were used for the induction of heterotopic bone, but with different volumes of BM, and the 4th group was used as control. Twelve animals were used in the experimental study (second phase).

\section{Pilot study}

Method for the induction of heterotopic ossification. All animals were anesthetized by intramuscular injections of $80 \mathrm{mg} / \mathrm{kg}$ ketamine and $8 \mathrm{mg} / \mathrm{kg}$ xylazine, receiving a booster dose if necessary. BM was then collected bilaterally from the iliac crest of the animal with a $25 \times 17-\mathrm{mm}$ puncture needle.

After collection, BM was implanted bilaterally in the quadriceps. For the implant, a thin needle $(0.3 \times 16 \mathrm{~mm})$ of the type used for insulin injection was inserted perpendicularly to the ventral side of the thigh.

The animals were divided into three groups, receiving $0.2,0.35$, and $0.5 \mathrm{mLBM}$, respectively. The minimum implant volume was adopted from published studies $(5,11)$. The maximum volume of BM was determined as the maximum volume supported by the animal as long as there was no leakage of liquid during the implant.

All animals were given oral doses of $20 \mathrm{mg} \cdot \mathrm{kg}^{-1} \cdot 24 \mathrm{~h}^{-1}$ Dipyrone $^{\circledR}\left(500 \mathrm{mg} / \mathrm{mL}\right.$ Eurofarma ${ }^{\circledR}$, Brazil) during the first 3 days for pain relief after the BM collection procedure.

The animals were euthanized 35 days after BM implantation, a period considered to be sufficient for the development of heterotopic bone formation $(5,11)$.

Evaluation methods. The rats were anesthetized for blood collection for serum alkaline phosphatase (ALP) determination and for the dissection of the left and right quadriceps. During the dissection, the muscles were periodically dripped with normal saline solution to prevent tissue desiccation. Still under anesthesia, the animals were given a lethal intracardiac dose of an anesthetic drug. Four tissue fragments were collected from each group for histological analysis, and another four (of the left quadriceps) were collected for spectrophotometric analysis.

The following parameters were evaluated in the pilot study group: mortality rate, mean serum ALP, and calcium percentage in the left quadriceps (Table 1). In addition to the histological analysis, a qualitative evaluation of the presence of heterotopic bone was performed.

The results obtained in the experimental study are reported as mean, median, minimum, maximum, and standard deviation. Repeated measure analysis of variance was used to evaluate the effect of time on weight (pre $\times 8$ $x 43$ days). Multiple comparisons were made by the least significant difference test. ALP data obtained before the experimental procedure were compared to data obtained 43 days after the procedure using the Student $t$-test for paired samples. The normality of the data was evaluated by the Shapiro-Wilk test, with $P$ values less than 0.05 considered to be statistically significant. Data were analyzed using the computer program Statistica v. 8.0 (Table 1).

\section{Experimental study}

Based on the results of the pilot study, we determined the most effective protocol for $\mathrm{HO}$ induction by correlating the volume of BM deployed, the death rate, levels of ALP, the amount of calcium in muscle, and bone formation rate. The volume of $0.35 \mathrm{~mL}$ was the most effective and thus chosen for the induction protocol to be tested.

The sample group consisted of 12 adult male Wistar albino rats ( $R$. norvegicus) weighing $350-390 \mathrm{~g}$, a size that would facilitate BM collection. The anesthetic induction was performed by an intramuscular injection of $80 \mathrm{mg} / \mathrm{kg}$ ketamine and $8 \mathrm{mg} / \mathrm{kg}$ xylazine before all the procedures (blood sampling for ALP evaluation, BM collection and $\mathrm{HO}$ induction, muscle sampling, and euthanasia).

$\mathrm{HO}$ induction was performed 1 week after blood sampling for ALP determination, so that the animals would have time for recovery after blood collection. The experiment lasted 43 days: on day 1 , blood was collected for ALP determination; on day $8, \mathrm{HO}$ induction was carried out by $\mathrm{BM}$ sampling from the iliac crest and re-injection in the quadriceps muscles, and on day 43, the animals were euthanized and blood and muscles were collected for analysis. The period between BM implantation and euthanasia was 35 days.

The methods used to detect induced heterotopic bone formation were the same as those in the pilot study. For histological analysis, slides were stained with HE. To confirm heterotopic bone formation, counterproof slides with Mallory's trichrome were performed.

\section{Results}

\section{Results of the pilot study}

The mortality rate was highest in the $0.5-\mathrm{mL}$ BM group (Table 1), a result related to the large volume of organic material collected from the iliac crest of these animals, and in the 0.2-mL group 1 animal died.

ALP levels increased with the 0.2-mL group showing a higher ALP level than the average of the other groups that received the implant of $B M$. The amount of calcium in the quadriceps was assessed by flame photometry, and the values are reported as $\mathrm{mg} \mathrm{Ca}^{2+} / \mathrm{g}$ muscle. The $0.35-\mathrm{mL}$ group obtained more $\mathrm{mg} \mathrm{Ca}^{2+} / \mathrm{g}$ than all the other groups (Table 1).

The percentage of heterotopic bone formation was assessed by histological analysis. The $0.2-\mathrm{mL}$ group showed $33.3 \%$ bone formation, whereas the $0.35-\mathrm{mL}$ group showed $100 \%$ heterotopic bone formation. The $0.5-\mathrm{mL}$ group was not suitable for analysis since only one of the animals survived and showed bone formation while the rest of the 
Table 1. Effect of bone marrow volume on mortality, serum alkaline phosphatase (ALP) and calcium levels in the left quadriceps.

\begin{tabular}{|c|c|c|c|c|c|c|}
\hline Bone marrow volume & $\mathrm{N}$ & $\begin{array}{l}\text { Mortality } \\
\text { rate }\end{array}$ & ALP (IU) & $\begin{array}{c}\text { Muscular } \\
\text { calcium (mg/g) }\end{array}$ & $\begin{array}{c}\text { Muscle weight } \\
\text { of } E G(g)\end{array}$ & $\begin{array}{l}\text { Weight of EG } \\
\text { (g) }\end{array}$ \\
\hline Control & 5 & $0 \%$ & $264 \pm 7.87$ & $0.235 \pm 0.06$ & - & - \\
\hline $0.2 \mathrm{~mL}$ & 4 & $25 \%$ & $239.3 \pm 135.1$ & $0.120 \pm 0.006$ & - & - \\
\hline $0.35 \mathrm{~mL}$ & 4 & $0 \%$ & $230 \pm 39.1$ & $0.4286 \pm 0.617$ & - & - \\
\hline $0.5 \mathrm{~mL}$ & 4 & $75 \%$ & $135 \pm 0$ & $0.1391 \pm 0$ & - & - \\
\hline $\begin{array}{l}\text { Experimental group } \\
(E G, 0.35-m L)\end{array}$ & 12 & $0 \%$ & $191.64 \pm 71.5$ & $0.16 \pm 0.01$ & $3.31 \pm 0.21$ & $381.3 \pm 14.78^{*}$ \\
\hline
\end{tabular}

Data are reported as means $\pm S D$. ${ }^{*} P<0.05$ when the weight obtained on the 8th and 43rd days was compared (ANOVA). Before and after the induction of $\mathrm{HO}$, the data had normal distribution (Shapiro-Wilk test).

group suffered premature deaths before this phase could be completed.

\section{Results of the experimental study}

The assessment was performed on 12 Wistar rats. Their weights increased significantly between the beginning and the end of the experiment (Table 1). ALP levels were compared between the 8th and 43rd day showing no statistical significance.

The amount of calcium in the quadriceps was assessed by flame photometry, and the values are reported as $\mathrm{mg}$ $\mathrm{Ca}^{2+} / \mathrm{g}$ muscle. The data obtained were compared to those of the pilot study indicating no statistical significance.

No statistical significance was detected for the weight of the quadriceps muscle; however, despite these results, histological analysis revealed heterotopic bone formation in all animals of the experimental group.

\section{Discussion}

At the end of the experimental study there was an increase in body weight, whereas ALP, muscle weight and $\mathrm{Ca}^{2+}$ values did not differ significantly (Table 1 ), although $100 \%$ heterotopic bone formation was observed in the animals of the $0.35-\mathrm{mL}$ BM group as assessed by histological analysis.

Heterotopic bone formation is usually generated by the implantation of demineralized bone matrix (10-13), more specifically by implantation of bone morphogenetic protein in ectopic sites $(10,14)$, or by implantation of BM stromal cells (15-17). Most of these models have variable repeatability, but the implantation of bone marrow to induce heterotopic bone formation can be demonstrated simply without the demand of time needed to prepare the material to be deployed. The induction procedure used in the present study was adopted from studies $(5,10,11)$ that have documented that 35 days are sufficient for heterotopic bone formation in the quadriceps of rabbits following implantation of $2 \mathrm{~mL}$ BM collected from the iliac crest of the animal. Namazi and
Mozaffarian (5) observed that after 35 days of BM implant in rabbits, heterotopic bone formation occurred in $83.3 \%$ of control animals. Dudkiewicz et al. (11), using the same methodology for $\mathrm{HO}$ induction, observed $97 \%$ heterotopic bone formation. In the present study, we detected $100 \%$ heterotopic bone formation in the quadriceps of Wistar rats.

A texture liquid, which is deposited in the recipient site by percutaneous injection (16), has osteogenic cells, and the resulting implantation forms bony capsules (18) when injected into the muscle tissue or the peritoneal cavity. This type of implant is a sufficient stimulus for osteogenesis $(19,20)$.

It was found that BM implantation in the quadriceps of animals induces heterotopic bone formation; however, care must be taken about the volume implanted. For this reason, the implantation of $0.35 \mathrm{~mL}$ BM was more suitable for the induction of heterotopic bone in Wistar rats as indicated by the low mortality rate and the level of ALP. This is important for the initiation of calcification (21) since it is associated with inflammatory processes and their modulation/regulation (22-31) of $\mathrm{Ca}^{2+}$ in muscle and bone formation demonstrated by histological analysis.

Loss of animal weight due to stress suffered as a result of manipulation, anesthetic procedures and collection of material for analysis is usually reported in the literature $(32,33)$. However, the animals used in the present study showed a weight gain, as expected for normal animals. We may infer that, despite the manipulation, anesthesia and BM implant, there was little or no interference creating stress in the animals and a weight loss (Table 1).

It is known that bone alkaline phosphatase (BAP) can be specifically used to assess osteoblast differentiation and that mineralization increases with decreasing BAP values. This leads to an increase in osteocalcin, a specific biochemical marker for bone formation (34). Despite the specificity of these tests, in the present study we chose ALP, which is used as a tracer of osteoblast activity and is indicated as a diagnostic method of $\mathrm{HO}(35,36)$. Besides being present in bone, ALP is also present in the intestine, 
liver, kidneys, and placenta but, despite its presence in these organs, its increased levels may be related to the increase in the amount of calcium in the joints and muscles (37), and ALP levels show $97.5 \%$ specificity for detecting bone activity (24). ALP levels in the experimental study did not differ significantly between the beginning and the end of the experiment.

In a study that used an implant of demineralized bone matrix to induce $\mathrm{HO}$ in 50 Wistar rats (28), evaluation of calcium concentration by flame spectrophotometry showed a significant increase compared to control. In the present study, calcium concentration in muscle was determined by flame spectrophotometry, assuming that, in case of the existence of bone, the calcium concentration of muscle would be higher, which was not detected in the present study (Table 1).

We chose histological analysis for the visualization of bone formation. Although radiography is commonly used as a diagnostic method for $\mathrm{HO}$ in experimental studies $(4,10)$, we choose not to use this method because the amount of BM implant was small and bone formation would be difficult

\section{References}

1. Castro AW, Greve JM. Ossificação heterotópica em pacientes com lesão medular traumática: associação com antígenos do sistema HLA. Acta Ortopédica Brasil 2003; 11: 102-109.

2. Lin L, Shen $Q$, Xue T, Yu C. Heterotopic ossification induced by Achilles tenotomy via endochondral bone formation: expression of bone and cartilage related genes. Bone 2010; 46: 425-431.

3. Balboni TA, Gobezie R, Mamon HJ. Heterotopic ossification: Pathophysiology, clinical features, and the role of radiotherapy for prophylaxis. Int J Radiat Oncol Biol Phys 2006; 65: 1289-1299.

4. Lounev VY, Ramachandran R, Wosczyna MN, Yamamoto M, Maidment AD, Shore EM, et al. Identification of progenitor cells that contribute to heterotopic skeletogenesis. J Bone Joint Surg Am 2009; 91: 652-663.

5. Namazi H, Mozaffarian K. Levothyroxin inhibits heterotopic ossification: an experimental study in rabbits. J Trauma 2008; 65: 849-851.

6. Araújo IF, Taricco LD, Cruz CL, Ares MJ, Cristante ARL. Ossificação heterotópica em pacientes neurológicos: atualizando conceitos. Med Reabil 2008; 27: 89-92.

7. Linan E, O'Dell MW, Pierce JM. Continuous passive motion in the management of heterotopic ossification in a brain injured patient. Am J Phys Med Rehabil 2001; 80: 614-617.

8. Huggins CB. Experimental osteogenesis. Proc Soc Exper Biol Med 1930; 27: 349-351.

9. Huggins $C B$. The formation of bone under the influence of epithelium of the urinary tract. Arch Surg 1931; 22: 377408.

10. O'Connor JP. Animal models of heterotopic ossification. Clin Orthop Relat Res 1998; 346: 71-80.

11. Dudkiewicz I, Cohen I, Horowitz S, Regev S, Perelman M, to identify in a conventional radiography. Radiographic findings in experimental research can be questionable because the volume of implant is usually small. Regarding the visualization of bone formation, when some opacity is radiographically present it is difficult to determine whether new bone is present or simply tissue edema resulting from material implant for $\mathrm{HO}$ induction. In studies that used a BM implant in the quadriceps of rabbits to study the influence of anti-inflammatory therapies, bone formation was observed in the muscle of control animals that received the implant of BM $(5,10)$, in agreement with the histological findings of the present experimental study.

Reliable animal models of $\mathrm{HO}$ that mimic pathologies in humans would be invaluable for the development of new treatments to combat heterotopic ossification $(2,5,8$ $12,28)$. Therefore, autotransplantation of $0.35 \mathrm{~mL} \mathrm{BM}$ in the quadriceps of Wistar rats can be an alternative induction protocol for $\mathrm{HO}$ studies since the procedure is simple and inexpensive, and the induction rate of bone formation within 35 days was $100 \%$.
Chechik A, et al. Colchicine inhibits heterotopic ossification: experimental study in rabbits. Isr Med Assoc J 2005; 7: 3134.

12. Urist MR. Bone: formation by autoinduction. Science 1965; 150: 893-899.

13. Urist MR, DeLange RJ, Finerman GA. Bone cell differentiation and growth factors. Science 1983; 220: 680-686.

14. Hogan BL. Bone morphogenetic proteins: multifunctional regulators of vertebrate development. Genes Dev 1996; 10: 1580-1594

15. Song J, Kiel MJ, Wang Z, Wang J, Taichman RS, Morrison SJ, et al. An in vivo model to study and manipulate the hematopoietic stem cell niche. Blood 2010; 115: 2592-2600.

16. Del Carlo RJ, Monteiro BS, Daibert APF, Pinheiro LCP. Medula óssea autógena. Uma alternativa de enxerto em ortopedia veterinária. Rev Ceres 2004; 51: 411-418.

17. Emans PJ, Spaapen F, Surtel DA, Reilly KM, Cremers A, van Rhijn LW, et al. A novel in vivo model to study endochondral bone formation; HIF-1alpha activation and BMP expression. Bone 2007; 40: 409-418.

18. Danis A. Étude de l'ossification dans les greffes de moelle osseuse. Acta Chir Belg 1957; 3 (Suppl): 1.

19. Budenz RW, Bernard GW. Osteogenesis and leukopoiesis within diffusion-chamber implants of isolated bone marrow subpopulations. Am J Anat 1980; 159: 455-474.

20. Ekelund A, Brosjo O, Nilsson OS. Experimental induction of heterotopic bone. Clin Orthop Relat Res 1991; 263: 102112.

21. Mota A, Silva P, Neves D, Lemos C, Calhau C, Torres D, et al. Characterization of rat heart alkaline phosphatase isoenzymes and modulation of activity. Braz J Med Biol Res 2008; 41: 600-609.

22. Sanchez de Medina F, Martinez-Augustin O, Gonzalez R, 
Ballester I, Nieto A, Galvez J, et al. Induction of alkaline phosphatase in the inflamed intestine: a novel pharmacological target for inflammatory bowel disease. Biochem Pharmacol 2004; 68: 2317-2326.

23. Kapojos JJ, Poelstra K, Borghuis T, Van Den Berg A, Baelde $\mathrm{HJ}$, Klok PA, et al. Induction of glomerular alkaline phosphatase after challenge with lipopolysaccharide. Int J Exp Pathol 2003; 84: 135-144.

24. Min JW, Um SW, Yim JJ, Yoo CG, Han SK, Shim YS, et al. The role of whole-body FDG PET/CT, Tc 99m MDP bone scintigraphy, and serum alkaline phosphatase in detecting bone metastasis in patients with newly diagnosed lung cancer. J Korean Med Sci 2009; 24: 275-280.

25. Chung JH, Park MS, Kim YS, Chang J, Kim JH, Kim SK, et al. Usefulness of bone metabolic markers in the diagnosis of bone metastasis from lung cancer. Yonsei Med J 2005; 46: 388-393.

26. Kantorowitz DA, Miller GJ, Ferrara JA, Ibbott GS, Fisher R, Ahrens CR. Preoperative versus postoperative irradiation in the prophylaxis of heterotopic bone formation in rats. Int $J$ Radiat Oncol Biol Phys 1990; 19: 1431-1438.

27. Reis HJ, Herr G, Küsswetter W. Nsaids and experimentally induced heterotopic ossification. Calcif Tissue Int 1991; 50 (Suppl 1): 64

28. Esewein SA, Sell S, Herr G, Jukema GN, Gaissmaier C, Bamberg $M$, et al. Superior efficacy in suppression of heterotopic bone formation using fractionated irradiation of $5 \mathrm{x}$ 2 Gy compared to a single dose of $7 \mathrm{~Gy}$. An experimental study in rats. Acta Orthoped Belg 2003; 62: 119-126.
29. Muthukuruman N, Reddid AH. Dose-dependence of a threshold for optimal bone induction by collagen bone matrix and ostogenin-enriched fraction. Collagen Rel Res 1988; 8: 433-441.

30. Urist MR, Iwata $\mathrm{H}$, Strates BS. Bone morphogenetic protein and proteinase in the guinea pig. Clin Orthop Relat Res 1972; 85: 275-290.

31. Urist MR, Jurist JM Jr, Dubuc FL, Strates BS. Quantitation of new bone formation in intramuscular implants of bone matrix in rabbits. Clin Orthop Relat Res 1970; 68: 279-293.

32. Balcombe JP, Barnard ND, Sandusky C. Laboratory routines cause animal stress. Contemp Top Lab Anim Sci 2004; 43: 42-51.

33. Gomes AR, Coutinho EL, Franca CN, Polonio J, Salvini TF. Effect of one stretch a week applied to the immobilized soleus muscle on rat muscle fiber morphology. Braz $\mathrm{J}$ Med Biol Res 2004; 37: 1473-1480.

34. Ratisoontorn C, Seto ML, Broughton KM, Cunningham ML. In vitro differentiation profile of osteoblasts derived from patients with Saethre-Chotzen syndrome. Bone 2005; 36: 627-634.

35. Shehab D, Elgazzar AH, Collier BD. Heterotopic ossification. J Nucl Med 2002; 43: 346-353.

36. van Kuijk AA, Geurts AC, van Kuppevelt HJ. Neurogenic heterotopic ossification in spinal cord injury. Spinal Cord 2002; 40: 313-326.

37. Rees JA, Ali SY. Ultrastructural localisation of alkaline phosphatase activity in osteoarthritic human articular cartilage. Ann Rheum Dis 1988; 47: 747-753. 